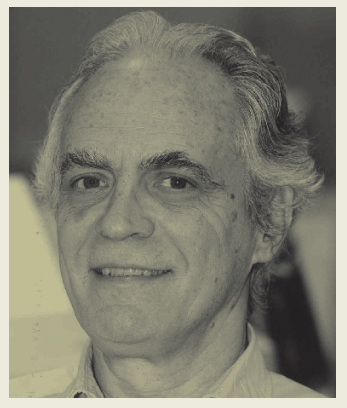

\title{
RIQUEZA CONCENTRADA, DESEQUILÍBRIO FISCAL E RETOMADA DO CRESCIMENTO
}

"No socialismo se distribui bem o que se produz mal. No capitalismo, é exatamente o contrário". Como todo lugar-comum, este último carrega boa dose de verdade: no capitalismo a riqueza material se expande, mas deságua nas mãos de poucos. A riqueza acumulada individualmente se traduz na aquisição de imóveis - rurais e urbanos -, metais preciosos e joias, obras de arte, títulos do mercado financeiro etc. A garantia da propriedade privada é indispensável: sem ela, a acumulação individual da riqueza produzida seria inviável.

Mas a riqueza alimenta-se do fluxo contínuo de valores, que tem origem nos setores produtivos, os quais dependem de investimentos. Quando estes enfraquecem, o montante da riqueza produzida diminui. Em outras palavras, o crescimento do produto interno bruto (PIB) sofre contração, podendo até mesmo tornar-se negativo, como aconteceu no Brasil entre 2014 e 2016. Nesse caso, a riqueza concentra-se ainda mais: os mais pobres mergulham profundamente na pobreza (desemprego), os mais ricos conservam suas posições ou se tornam levemente menos ricos. Isso ocorre quando os investidores percebem que o déficit e a dívida pública aumentam de maneira descontrolada. Alegando adotar uma política keynesiana de estímulo à demanda, o governo gasta muito mais do que arrecada eventualmente tentando melhorar a vida dos mais pobres, mas o resultado, em geral, é o inverso do pretendido.

A retomada do crescimento da economia interessa a todos... ricos, pobres ou remediados. No entanto, no atual contexto brasileiro, torna-se inviável fazê-lo aumentando o déficit e a dívida pública: inflação e disparada dos juros esperam emboscadas no virar da esquina. Cientes disso, os investimentos privados retraem-se ainda mais e a crise agrava-se.

Sendo assim, existem dois caminhos para sair da recessão que ainda enfrentamos:

- equilibrar as contas públicas, garantindo juros e taxas de inflação baixos e estimulando o investimento privado. É o que o governo vem tentando fazer - na velocidade de uma tartaruga -, defendendo a bandeira da aprovação da reforma da previdência;

- agregar ao anterior uma reforma tributária que, além da simplificação e da nova repartição das receitas entre a União, os estados e os municípios, promova carga tributária mais alta entre os mais ricos - pessoas físicas -, aumentando a arrecadação sem afetar as empresas produtivas. Tal contribuição seria um "investimento" no ajuste fiscal, que, alcançado mais rapidamente, beneficiaria a todos. As propostas de reforma tributária em circulação, infelizmente, não incluem essa possibilidade.

No primeiro caso, a retomada é mais lenta; no segundo, mais rápida. Quanto mais célere a volta do crescimento do PIB, mais curta a fase de transição, uma vez que o tonificante por excelência do aumento da arrecadação é o próprio crescimento da economia.

Ao mesmo tempo, as turbulências políticas de nossos vizinhos, somadas às emanadas de Brasília, podem comprometer a volta dos investimentos privados: estes também demandam estabilidade política nos médio e longo prazos e, sem ela, fica difícil. 